Indonesian Journal of EFL and Linguistics

Vol. 5 No. 2, 2020

eISSN: 2503-4197, pISSN: 2527-5070

www. indonesian-efl-journal.org

\title{
Corpus-Based Analysis of the Most Frequent Adjective on Covid-19
}

\author{
Idda Astia \\ Universitas Airlangga \\ e-mail:idda.astia@gmail.com \\ Sofi Yunianti \\ Universitas Muhammadiyah Surabaya \\ e-mail: sofiyunianti@fkip.um-surabaya.ac.id
}

\begin{abstract}
:
This study aims to investigate the type of adjectives in the most frequent adjectives and also the use of the adjective functions on academic writing about COVID-19. This study was conducted by using a corpus tool named sketchengine. The method of this study was a mixed-method by combining quantitative and qualitative approaches. The source of the data was corpus about COVID-19 academic writing due to the fact that COVID-19 has been the trending topic around the globe and also became an international concern. There were several data collection steps; those were first, knowing the most frequent adjective in the COVID-19 corpus by choosing a wordlist. Second, the data were taken 20 the most frequent adjectives used in COVID-19 corpus because 20 data have already represented the most frequent adjectives. Third, it chose the concordance to comprehend the function of the adjective in the COVID-19 corpus. Fourth, 20 the most frequent adjectives were inputted one at a time on concordance. Fifth, the data were analyzed based on the related theory. Finally, it is inferred that the adjective type on the most frequent adjective is a describing adjective, which has the function to frame the condition, situation and characteristic of the noun on the COVID-19 cases.
\end{abstract}

Keywords: adjective, corpus, covid-19 
Idda Astia, Sofi Yunianti

\section{INTRODUCTION}

Coronavirus or COVID-19 is an infectious disease which attacks the respiratory system. It attacks all people, from infants to elders. Bogoch et al.; Lu and Tang in Rothan \& Byrareddy (2020) explained that it was begun in Wuhan, Hubei Province, China, when the people contacted the wet animal or seafood wholesale market. Previously, there were such pandemic happened in the previous years, for example severe acute respiratory syndrome or SARS outbreak in 2002 and Middle East respiratory syndrome or MERS outbreak in 2012 which emerge in the human population (Unhale et al., 2020). Now, COVID-19, which was started in December 2019 until present and becomes a pandemic since it has spread out worldwide. Although there were such infectious diseases in previous years, such as bird influenza, pig influenza, MERS and even SARS but COVID-19 is the worst. It was proven that SARS needed in about eight months to cause the victims and MERS in eight years, but COVID-19 had caused more victims in just two and a half months (Hui et al. in Contini et al., 2020). Consequently, COVID-19 is a public health emergency of international concern (Cortegiani et al., 2020). According to Worldometer (2020) about COVID-19, the last update on July $27^{\text {th }}, 2020$, its cases reach $16,413,954$, with the death cases reach 652,057 . Due to the fact that it quickly has caused death cases, it becomes a trending topic all over the globe. Consequently, there are heaps of news that always report and update the pandemic's condition and situation.

Furthermore, describing the situation and condition of COVID-19, the scholars need to apply the adjective. It literally can be applied for framing the issues due to the fact that it is directly able to modify the noun in which noun and verb are not able to do it (Baker, 2003, p192). The adjective is the words capable of condensing, evaluating, classifying entities or describing qualities (Marzá, 2013). Adjective plays a relevant role by modifying, adjusting, modulating or elaborating the meanings of nouns. (Huddleston and Pullum in Jing, 2011; Dixon, 2005; Durán-Muñoz, 2019;). Then, adjectives are probably the most prototypical way to express the qualification of a noun, even when words originally relating to other syntactic categories can also function as adjectives, as is the case of the present and past participle of terms and also of nouns pre-modifying other nouns (Edo Marzá, 2017). Due to the fact that the adjective is not the same as a noun because the function is to modify the noun so that adjective is never independent (Panagiotidis, 2016).

Furthermore, collecting thousands of adjectives are not effortless because it takes time to collect them. The linguistic knowledge of adjectives can be gathered from available corpora (Kartal, 2017). The term of corpus is usually applied for a text collection designed for linguistics research to reflect or identify some language aspect (McEnery \& Hardie in Artha, 2018; Sinclair, 1991 p.17; Stubbs, 2001). Swales in Nashina (2010) also adds that corpus linguistics and its software are invaluable for disciplinary and genre studies in comparing language, knowledge, experience, attitude and culture. Moreover, the use of corpus analysis is a technique to investigate the issues related to linguistics characteristicsin academic texts (Rappen in Mazdayasna \& Firouzi, 2013). 
There were numerous studies using the corpus approach, especially in observing adjective such as the use of corpus to analyze the adjective in imaging or promoting hotel and tourism (Durán-Muñoz, 2019; Edo Marzá, 2017; Marzá, 2013). The use of corpus approach was applied to figure out the adjective in children short story and novel (Mia, 2018; Salim \& Saad, 2016). Analyzing the adjective in contemporary or written and spoken English can use corpus as a tool (Jing, 2011; Tran, 2013). Corpus study also was used to analyze the adjective in online users, such as Amazon.com (Altun, 2019). Corpus could be used to figure out the Greek adjective (Fragaki, 2010). To figure out the most frequent adjective in the academic writing, such as social sciences, technology, medical sciences, linguistics, literature and technical by applying corpus (Ağçam \& Özkan, 2015; Jitpranee, 2017; Kartal, 2017; Mazdayasna \& Firouzi, 2013; Nashina, 2010). Those previous studies used corpus to investigate the most frequent adjective on the other hand, and those studies only observed the quantity and type of the most frequent adjective. Therefore, the gap of the research is finding the adjective function of COVID-19 current issue.

Recently, COVID-19 becomes the most trending research by the scholars. It causes the abundance of articles in discussing about COVID-19. The use of adjective is applied in describing the condition and situation. Consequently, this study investigates the most frequent adjective type used in academic writing to describe COVID-19; and elaborate the function of the adjective in describing the cases of COVID-19 in academic writing.

\section{LITERATURE REVIEW}

Adjective literally can be applied for framing the issues due to the fact that it is directly able to modify the noun in which noun and verb are not able to do it (Baker, 2003, p192). Moreover, (Khamying, 2007) classified the type of adjective into 11 classifications, those are descriptive adjective, proper adjective, quantitative adjective, numeral adjective, demonstrative adjective, interrogative adjective, possessive adjective, distributive adjective, emphasizing adjective, exclamatory adjective, and relative adjective. Each of types has different function, those are (1) descriptive adjective is to attribute or qualify people, animal, things, or places in order to describe its features, such as the rich man lives in the big house. (2) proper adjective is to modify noun in terms of the nationality, this type is originated from proper noun, such as she employs a Chinese book. (3) quantitative adjective is to modify noun for particular details in quantifying, such as, such as he ate much rice at school yesterday. (4) numeral adjective is to modify noun for particular details in exact quantifying which is divided to three classification: cardinal (my foot has five toes), ordinal (she is the first child in her family) and multiplicative (some roses are double). (5) demonstrative adjective is to show the noun it modifies is singular or plural and whether the position of the noun is near or far from the person who is speaking or writing, such as I invited that man to come in. (6) interrogative adjective is to modify noun as a question form, such as what book is he reading in the room?. (7) possessive adjective is to express possession of a noun by someone or something, such as this is my table. (8) distributive adjective is to modify noun by dividing or separating into different parts, such as every soldier is punctually in 
his place. (9) emphasizing adjective is to modify noun by highlighting or emphasizing the texts, such as Supansa is my own girl-friend. (10) exclamatory adjective is to modify noun by using interjection words, such as what a man he is. (11) relative adjective is to modify noun and combine sentence which are related between the first and second sentences, such as give me what money you have.

There are two previous studies about adjective function, first, it is a syntactic and semantic analysis on Nadia Murad's Nobel lecture (Alwasilah \& Mahdi, 2020); and second, it is the communicative function of adjective-noun order in English (Hesseltine $\&$ Davis, 2020). The first previous study only discusses adjective phrases in syntax and its meaning in semantics in Nadia Murad's Nobel lecture. Moreover, the second study elaborates the relational placement in English words known as adjective and noun. Therefore, to fill the gap research, this study analyzes the function of the adjective.

\section{RESEARCH METHODOLOGY}

\subsection{Design and Source of Data}

This study used a mixed-method. It was chosen because of its strength of drawing on qualitative and quantitative research and minimizing the limitation of both approaches (Creswell \& Creswell, 2018; Onwuegbuzie \& Collins, 2007). The use of quantitative is to figure out the amount of frequency in the adjective and the use of qualitative is to elaborate the function of adjective to frame the COVID-19 issues. The design in mixed method was explanatory sequential mixed methods. The study was conducted in quantitative research then analyzed the results in explaining them in detail by applying the qualitative research (Creswell \& Creswell, 2018). The source of the data was corpus about COVID-19. The corpus about COVID-19 was taken from the scientific writing or academic research collections. Those corpuses were from sketch engine which could be accessed through www.sketchengine.au. It was a tool which provided mega corpus which contains the multitude academic researches.

\subsection{Instruments}

Data in this study were collected through documentation. It was taken by using several steps. First, it chose a wordlist on sketch engine to figure out the most frequent adjective in the COVID-19 issues. In the corpus composition, the result of wordlist frequency indicated the coherence and appears to be well balanced and representative (Marzá, 2013; Sinclair, 1991). There were heaps of choices in wordlist, such as the classification of noun, adjective, verb, etc. Due to the fact that this study concentrated in adjective, it chose adjectives in wordlist. Second, there were 70,795 lists of adjectives, so that the data were taken 20 the most frequent adjectives which used in COVID-19 issues because 20 data have already represented the most frequent adjectives. 
Corpus-Based Analysis of the Most Frequent Adjective on Covid-19

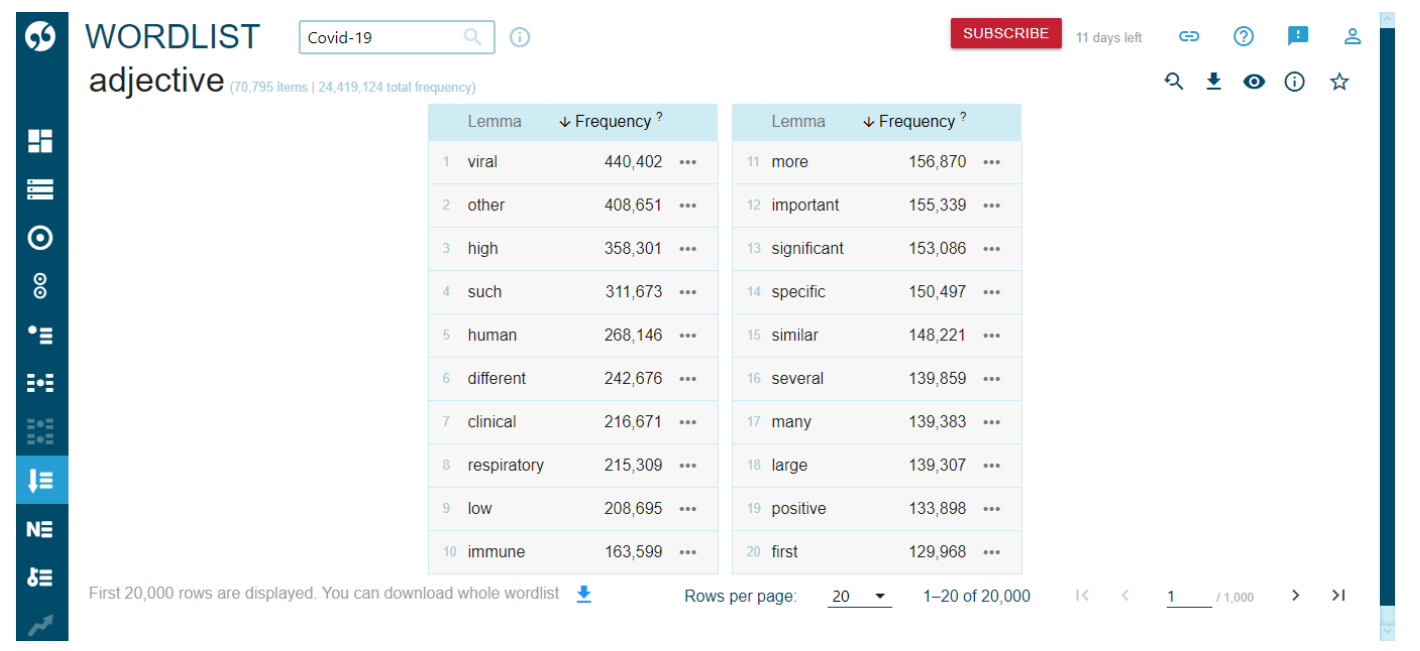

Picture 1.20 the most frequent adjectives in COVID-19 issues on sketch engine

\subsection{Data Analysis Procedure}

There were some steps to analyze the data after the data collected. The data analyze separately between quantitative and qualitative databases. Analyzing quantitative to figure out the most frequent adjectives was by giving the coding in the data collected. Coding was the process of labeling the data, which was decided in advance in data collected (Cohen et al., 2018). Analyzing qualitative to comprehend the function of adjectives in the context of COVID-19 was by choosing the concordance tools on sketch engine. A list of all the contexts in which a word occurs in a particular text is called a concordance (Lindquist, 2009). There were 20 the most frequent adjectives which inputted one at a time on concordance. Maintaining the findings' trustworthiness, the 300 most frequent adjective from 70,795 was attached in the end as an appendix.

\section{FINDING AND DISCUSSION}

This section described the finding of the most frequent adjectives in COVID-19 issues gathered during the data collection.

Table 1. Eleven adjective types found

\begin{tabular}{lcc}
\hline \multicolumn{1}{c}{ Type of Adjectives } & Percentage (100\%) & Rank \\
\hline Descriptive & $70 \%$ & 1 \\
\hline Quantitative & $20 \%$ & 2 \\
\hline Emphasizing & $5 \%$ & 3 \\
\hline $\begin{array}{l}\text { Numeral } \\
\text { (Ordinal number) }\end{array}$ & $5 \%$ & 3 \\
\hline
\end{tabular}


Idda Astia, Sofi Yunianti

\subsection{Descriptive Adjective}

The most frequent adjectives in COVID-19 issues were descriptive adjective which showed in $70 \%$ (see table 1). The descriptive adjective function was to attribute the noun for reflecting its features (Khamying, 2007). There were 14 adjectives from 20 adjectives which included in the descriptive adjective. To describe the function of the adjective, there were first 7 adjectives from 14 adjectives which taken.

Table 2. The list of the most frequent adjective in descriptive adjective

\begin{tabular}{cccc}
\hline $\begin{array}{c}\text { List of the most } \\
\text { frequent adjective }\end{array}$ & Frequency & $\begin{array}{c}\text { List of the most } \\
\text { frequent adjective }\end{array}$ & Frequency \\
\hline Viral & 440,402 & Immune & 163,599 \\
High & 358,301 & Important & 155,339 \\
Human & 268,146 & Significant & 153,086 \\
Different & 242,676 & Specific & 150,497 \\
Clinical & 216,671 & Similar & 148,221 \\
Respiratory & 215,309 & Large & 139,307 \\
Low & 208,695 & Positive & 133,898 \\
\hline
\end{tabular}

First, the word "viral" was often applied by the scholars in describing the issues of COVID-19. This sentence was one of the sentences which taken from the corpus about COVID-19 issues, it is framework explicitly combines knowledge of viral infection times within the genetic transmission. Based on that sentence, it could be seen the use of the adjective which it was used to modify the noun. Framing the condition and situation of the infection which has spread out around the globe, the scholars applied the adjective viral because the infection became a trending topic recently. Consequently, the adjective "viral" was applied to modify the noun "infection" that had the framing of the infection's situation. Second, the word "high" was often applied after the word viral in describing the COVID-19 issues. This sentence was one of the sentences which taken from the corpus about COVID-19 issues, it is in order to detect an organism with a high degree of specificity (reduce false positives). Based on the sentence, it could be seen that the adjective applied to modify noun. The adjective "high" was used to describe the level of the condition of noun. Due to the fact that the COVID-19 issues have been the concern of the citizen around the globe, so as the scholars preferred to apply the adjective "high". Consequently, the adjective "high" was applied to modify the noun "degree of specificity" which had the framing about the level of position about the condition.

The word "human" was number three for the most frequent adjective which used by scholars in describing the situation about COVID-19 issues. This sentence was one of the sentences which taken from the corpus about COVID-19 research, it is generates $a$ nonlocal pattern of human mobility, sharply reducing the time of travel. Based on the sentence, it could be seen that the adjective was applied to modify the noun. The adjective "human" was chosen to describe the characteristic of the noun "mobility" which done by human. Due to the fact that the COVID-19 issues related to human so that the choice of the adjective which was able to describe the noun "mobility" was 
human. The word "different" was number four for the most frequent adjective which written by the scholars in describing the condition about COVID-19 issues. The sentence was one of the sentences which taken from the corpus about COVID-19 research, it is ... collection nose swabs from the two time-points were collected from different individual from twenty general practitioners (GP) practices from ... Based on the sentence, the adjective was used to describe the situation by classifying the noun. The adjective "different" was chosen to classify the noun "individual" in the COVID-19 research which to describe the individual were not the same. Due to the fact that the COVID-19 caused a huge of victims, the scholars were taken the various subjects for their research to get the authentic result. Consequently, the scholars applied the adjective "different" to modify the noun.

Then, the word "clinical" was number five for the most frequent adjective written by the scholar in elaborating the meaning of noun about COVID-19 research. The sentence was one of the sentences taken in COVID-19 corpus, it is Unless the incubation is only a small fraction of the duration of clinical symptoms, and fever in particular, syndromic screening is likely to ... Based on the sentence, the adjective was used to describe the noun by explaining or making the noun more specific. The adjective "clinical" was chosen to elaborate on the noun "symptoms" because COVID-19 had some symptoms that needed to be explained more specifically. Consequently, the scholars decided to apply the adjective "clinical". Next, the adjective "respiratory" was applied in the COVID-19 corpus. The function of the adjective could be seen through the sentence, it is Suspected cases were identified as having fever or respiratory symptoms, and history of exposure to wildlife in Wuhan seafood ... Based on sentence, the function of adjective "respiratory" was to elaborate the noun. The noun "symptoms" was elaborated clearly, which related to respiration. Because COVID-19 had some symptoms especially related to respiration, the scholars describe using the adjective "respiratory". Low was the seventh adjective used by scholars in the COVID-19 corpus. The function of the adjective could be seen through the sentence, it is ... factors make enzymatic assays difficult for field use or for use in low resource areas without modern lab infrastructure. Based on the sentence, the function of the adjective was to describe position of the condition on COVID-19. To describe the level condition of the noun "resource area" in academic writing of COVID-19, the scholars applied the adjective "low".

\subsection{Quantitative Adjective}

The quantitative adjective is the second of the most frequent adjective, which showed $20 \%$ (see table 1). A quantitative adjective's function is to modify noun for particular details in quantifying (Khamying, 2007). There are 4 adjectives from 20 adjectives which included in the quantitative adjective. To describe the function of the adjective, there were first 2 adjectives from 4 adjectives which taken. 
Idda Astia, Sofi Yunianti

Table 3. The list of the most frequent adjective in quantitative adjective

\begin{tabular}{cc}
\hline $\begin{array}{c}\text { List of the most frequent } \\
\text { adjective }\end{array}$ & Frequency \\
\hline Other & 408,651 \\
More & 156,870 \\
Several & 139,859 \\
Many & 139,383 \\
\hline
\end{tabular}

In the quantity of adjective, the most frequent adjective was applied by the scholars in the COVID-19 academic writing was other. It was often applied by the scholars in modifying the noun in the issues of COVID-19. This sentence was one of the sentences taken from the corpus about COVID-19 academic writing, it was ... 3) infectious (I) able to transmit virus to other hosts and 4) Recovered state $(R)$-where the host ... It could be seen that the scholars preferred the adjective "other" to modify the noun which described the quantity with the uncertain amount. After the adjective "other", the following adjective applied by the scholars in the COVID-19 corpus, was "more". Based on the sentence taken from the COVID-19 corpus, it was ... be enhanced both within and 72 across countries at risk, as more people could benefitfrom vaccination without depriving 73 others. It could be seen that the function of this adjective was to count the amount of the noun, but without showing the uncertain amount due to the fact, there was not exactly the number mentioned.

\subsection{Emphasizing Adjective}

In the most frequent adjective, emphasizing adjective showed after descriptive adjective and quantitative adjective. It showed 5\% (see table 1) in using adjective in COVID-19 issues. The function of emphasizing adjective is to modify noun by highlighting or emphasizing the texts (Khamying, 2007). There are only 1 adjective from 20 adjective which included in emphasizing adjective. It used was "such" and its frequency was 408,651 . This sentence was one of the sentences which taken from the corpus about COVID-19 issues, it is ... can cause and our limited understanding of how such disease spread. Based on the sentence, it could be seen that the adjective "such" applied by the scholars to highlight the noun which was modified due to the fact that the choice of that adjective was to highlight the noun closely and specifically in the issues of COVID-19. Consequently, the adjective "such" was applied to modify the noun "mobility" in COVID-19 issues.

\subsection{Numeral Adjective}

The show of numeral adjective was same as demonstrative adjective. It showed $5 \%$ (see table 1) in using COVID-19. The function of numeral adjective is to modify noun for particular details in exact quantifying (Khamying, 2007). There are only 1 adjective from 20 adjective which included in numeral adjective. It used was "first" and its frequency was 129,968 . This sentence was one of the sentences which taken from the corpus about COVID-19 issues, it is ... but not with presence of Streptococcus in the first infection or with detection of $S$. pneumonia ... Based on the sentence, it could be seen that the 
adjective "first" used to modify the noun about quantity with exact amount. The adjective "first" was included in ordinal number which show the quantity hierarchically. Consequently, the adjective "first" was applied to modify the noun "infection" to show the amount hierarchically. (cardinal number)

Furthermore, what are the most the types of adjectives in the most frequent adjective on the academic writing of COVID-19? How is the use of the function of the adjective on COVID-19 corpus? This study found that the use of adjectives connected to the framing of the certain cases. In these views (Altun, 2019; Durán-Muñoz, 2019; Edo Marzá, 2017; Fragaki, 2010; Jing, 2011; Jitpranee, 2017; Kartal, 2017; Marzá, 2013; Mazdayasna \& Firouzi, 2013; Mia, 2018; Nashina, 2010; Salim \& Saad, 2016; Tran, 2013) revealed that the adjectives could show the condition, situation or even the characteristics of the objects. This study also agreed that the adjectives could be used for imaging the object and it also could be used for evaluating the object. It was not only imaging or evaluating the object but also framing the issues. Those studies used corpus as a tool to collect the data. This study was also conducted to figure out the type of adjective on the most frequent adjectives on the COVID-19 academic writing, and the function of the adjective applied to frame the condition and situation of the object. The previous studies observed the academic articles or customer views as data. On the other hand, this study observed the trending topic worldwide, which has been an international concerned. It was COVID-19 cases. The data was collected through a corpus of academic articles about COVID-19.

\section{CONCLUSION}

This study concludes that the type of the adjective in the most frequent adjectives on the COVID-19 cases in academic writing were descriptive adjective which had the function to describe, elaborate, classify or frame the condition, situation or even the characteristics of the noun. Then, the second type applied is quantity adjective. It has the function to modify the noun in quantifying the uncertain amount. The last is emphasizing adjectives and numeral adjective which have the same position in the most frequent adjectives in the COVID-19 issues. The emphasizing adjectives have the function to highlight the noun in the COVID-19 issues while the numeral adjectives have the function to show the exact amount of the noun. Literally, there were a huge of adjective words on the other hand, the scholars preferred to choose those adjectives (see picture 1) for their academic writing due to the fact that those adjectives represented the COVID-19 cases. This study provided better understanding about the use of adjective and also the choice of adjective related to the topic itself.

\section{REFERENCES}

Ağçam, R., \& Özkan, M. (2015). A Corpus-based Study on Evaluation Adjectives in Academic English. Procedia - Social and Behavioral Sciences, 199, 3-11. https://doi.org/10.1016/j.sbspro.2015.07.480

Altun, L. (2019). A Corpus Based Study: Analysis of the Positive Reviews of 
Idda Astia, Sofi Yunianti

Amazon.com Users. Advances in Language and Literary Studies, 10(1), 123. https://doi.org/10.7575/aiac.alls.v.10n.1p.123

Alwasilah, A. W., \& Mahdi, S. (2020). Syntactic and Semantic Analysis on Nadia Murad's Nobel Lecture. Linguistik: Jurnal Bahasa \& Sastra, 5(1), 80-88. https://doi.org/10.31604/linguistik.v5i1.80-88

Artha, A. F. (2018). Revolusi Pemerintahan, Sudahkah Berevolusi? Kolokasi Adjektiva Kata "Indonesia" dalam COCA dan COHA pada Periode Pemerintahan Orde Lama, Orde Baru dan Era Reformasi. Etnolingual, 2(1), 56-71.

Baker, M. C. (2003). Lexical Categories: Verbs, Nouns, and Adjectives. Cambridge University Press.

Cohen, L., Manion, L., \& Morrison, K. (2018). Research Methods in Education (8th ed.). Routledge.

Contini, C., Nuzzo, M. Di, Barp, N., Bonazza, A., Giorgio, R. De, \& Rubino, S. (2020). The novel zoonotic COVID-19 pandemic : An expected global health concern. The Journal of Infection in Developing Countries, 14(3), 254-264. https://doi.org/10.3855/jidc.12671

Cortegiani, A., Ingoglia, G., Ippolito, M., Giarratano, A., \& Einav, S. (2020). A systematic review on the efficacy and safety of chloroquine for the treatment of COVID-19. Journal of Critical Care, 57, 279-283. https://doi.org/10.1016/j.jcrc.2020.03.005

Creswell, J. W., \& Creswell, J. D. (2018). Research and Design Qualitative, Quantitative and Mixed Methods Approaches. In Thousand Oaks California (5th ed.). SAGE.

Dixon, R. M. W. (2005). A Semantic Approach to English Grammar (2nd ed.). Oxford University Press.

Durán-Muñoz, I. (2019). Adjectives and their keyness: A corpus-based analysis of tourism discourse in English. Corpora, 14(3), 351-378. https://doi.org/10.3366/cor.2019.0178

Edo Marzá, N. (2017). A Comprehensive Corpus-based Study of the Use of Evaluative Adjectives in Promotional Hotel Websites. ODISEA. Revista de Estudios Ingleses, 12, 97-123. https://doi.org/10.25115/odisea.v0i12.222

Fragaki, G. (2010). A corpus-based categorization of Greek adjectives. 5th Corpus Linguistics Conference, 1-19.

Hesseltine, K., \& Davis, J. (2020). The communicative function of adjective-noun order in English. Word, 66(3), 166-193. https://doi.org/10.1080/00437956.2020.1793499

Jing, C. (2011). A Corpus-Based Study of Adjectives in Contemporary English. City University of Hong Kong.

Jitpranee, J. (2017). A Study of Adjective Types and Functions in Popular Science Articles. International Journal of Linguistics, 9(2), 57. https://doi.org/10.5296/ijl.v9i2.10811

Kartal, G. (2017). A corpus-based analysis of the most frequent adjectives in academic texts. Teaching English with Technology, 17(3), 3-18.

Khamying, S. (2007). Advanced English Grammar for high learner. V.J. Printing. 
Lindquist, H. (2009). Corpus Linguistics and the Description of English. Edinburgh University Press.

Marzá, N. E. (2013). The Formation of the Image of Top-Ranked Hotels through Real Online Customer Reviews: A Corpus-Based Study of Evaluative Adjectives as Image-Formers/Providers. International Journal of English Linguistics, 3(4). https://doi.org/10.5539/ijel.v3n4p15

Mazdayasna, G., \& Firouzi, M. (2013). A Corpus Based Study of Adjectives in Literary and Technical Texts. Journal of Foreign Language Teaching and Translation Studies, 2(1), 2645-3592.

Mia, R. (2018). The Corpus Analysis of the Most Frequently Used Adjective in the Children Short Story for Middle School Students. State Islamic Institute Tulungagug.

Nashina, Y. (2010). Evaluative Meanings and Disciplinary Values: A Corpus-based Study of Adjective Patterns in Research Articles in Applied Linguistics and Business Studies (Issue September 2010). University of Birmingham.

Onwuegbuzie, A. J., \& Collins, K. M. T. (2007). A Typology of Mixed Methods Sampling Designs in Social Science Research. The Qualitative Report, 12(2), 281316. https://doi.org/10.1016/j.bbi.2003.12.001

Panagiotidis, P. (2016). Rethinking adjectives. May, 1-14. https://doi.org/10.13140/RG.2.2.26713.31841

Rothan, H. A., \& Byrareddy, S. N. (2020). The epidemiology and pathogenesis of coronavirus disease (COVID-19) outbreak. Journal of Autoimmunity, 109(February), 102433. https://doi.org/10.1016/j.jaut.2020.102433

Salim, H., \& Saad, N. N. (2016). Portraying the protagonists: A study of the use of adjectives in harry potter and the deathly hallows. International Journal of Applied Linguistics and English Literature, 5(6), 259-264. https://doi.org/10.7575/aiac.ijalel.v.5n.6p.259

Sinclair, J. (1991). Corpus, Concordance, Collocation. Oxford: Oxford University Press.

Stubbs, M. (2001). Words and Phrase: Corpus Studies of Lexical Semantics. Oxford: Blackwell Publishing.

Tran, L. A. (2013). A Corpus-based Analysis of the Evaluative Adjectives Interesting and Nice in Written and Spoken English. Hawaii Pacific University TESOL Working Paper Series 11, 2-28.

Unhale, S. S., Ansar, Q. B., Sanap, S., Thakhre, S., \& Wadatkar, S. (2020). A REVIEW ON CORONA VIRUS ( COVID-19 ). World Journal of Pharmaceutical and Life Sciences, 6(4), 109-115.

Worldometer. (July 27th 2020). Citing Internet sources URL https://www.worldometer.info/coronavirus 